\title{
Environmental influence on the secondary productivity and fish abundance in coastal fishing grounds off Mangalore, south-eastern Arabian Sea
}

\author{
SUJITHA THOMAS, A. P. DINESHBABU, K. M. RAJESH, PRATHIBHA ROHIT, \\ G. D. NATARAJA AND P. MISHAL* \\ Mangalore Research Centre of ICAR-Central Marine Fisheries Research Institute, Mangalore - 575 001, \\ Karnataka, India \\ ${ }^{*}$ ICAR-Central Inland Fisheries Research Institute, Barrackpore, Kolkata - 700 120, West Bengal, India \\ e-mail: sujithacmfri@yahoo.co.in
}

\begin{abstract}
Environmental parameters influence the productivity and abundance of fish in marine ecosystems. In this study, we attempted to analyse the relationship between environmental parameters and abundance of fish in trawling grounds in south-eastern Arabian Sea along the coast of Karnataka. Among the 85 species of finfishes and shellfishes caught in the trawling grounds, 41 finfish species, 24 crustaceans, 18 molluscs and two echinoderms were recorded. Seasonal differences were seen in biomass with the highest biomass during the post-monsoon period (October-January). Water temperature and nutrients were the key contributing factors of seasonal differences in the biotic communities studied. Season specific diagnostic species were identified using SIMPER analysis. Squilla which formed the major prey item of most of the demersal fishes dominated $(>40 \%)$ coastal grounds throughout all seasons. This could be considered as a fishery indicator of the region. The dominance and abundance of copepods was found to be influenced by sea surface temperature (SST) and nutrients. The results of the study have implications on the fishery, knowledge on environmental factors influencing the abundance and importance of non-commercial species in sustaining the fishery in the region.
\end{abstract}

Keywords: Arabian Sea, Coastal fishing, Environment, Fish abundance, Productivity, Season

\section{Introduction}

Fish landing estimates along the Indian coast have shown that more than $50 \%$ of the catch is contributed by trawlers (CMFRI, 2014). Marine fish catch statistics from Karnataka shows that trawlers harvest more than $70 \%$ of the total marine landings of the state (CMFRI, 2013). Major exploitation occurs along the Mangalore and Malpe coasts, which accounts for more than $53 \%$ of the total marine fish landings and $43 \%$ of trawl fisheries of Karnataka (Dineshbabu and Radhakrishnan, 2009). Several studies have reported on trawl fisheries along the Karnataka coast (Kurup et al., 1987; Mohammed et al., 1998; Dineshbabu et al., 2012, 2013). However very few studies have addressed the relationship between fish abundance in fishing grounds of Karnataka and the influence of environmental parameters on fish biomass in these grounds.

Fish abundance in a region is influenced by hydrographic parameters and productivity of the area, which includes both phytoplankton and zooplankton. Zooplankton, which are the primary consumers in the food chain, play crucial role in the marine ecosystem and form major food item of many economically important fishes in the sea.
The plankton biomass in the ecosystem is a crucial factor for fish production (Roy et al., 2010). Previous studies have investigated the relationship between zooplankton population and fishery in the Arabian Sea (Chidambaram and Menon, 1945; Subrahmanyan, 1959, 1973) and reported on seasonal changes in the species composition and biomass of the plankton as well as fishes. These changes were attributed to monsoon currents.

Hydrographic parameters influence the abundance and variations in zooplankton population (Bianchi et al., 2003). Climatic variability is known to cause changes in plankton population. Short and long-term environmental variations cause changes in the species composition and seasonal shifts in the aquatic ecosystems (Edwards et al., 2001; Alheit et al., 2005). Hence any influence of hydrographic and environmental parameters on plankton populations is thought to influence the fish abundance of the area through the food chain. Therefore this study analysed the influence of hydrographic parameters on zooplankton biomass and fish abundance in the coastal trawling grounds off the Mangalore coast in south-eastern Arabian Sea. This facilitated identifying the changes in community structure in relation with the hydrographic parameters over several years. 
Further, knowledge on seasonal variations in zooplankton population in the trawling grounds helps in understanding the changes in the fish stock which in turn can contribute towards managing these resources. The study envisioned to assess the seasonal patterns of fish distribution in the trawling grounds, the dominant species present, correlating its abundance with hydrographic variables and to provide baseline data for ecosystem-based management of coastal waters. The study also throws light on the crucial species in the fishing grounds that influence the catch of commercial species in a region.

\section{Materials and methods}

Study area

The study was conducted during 2007 - 2011 off the Mangalore coast in south-eastern Arabian Sea at a depth of 10-30 $\mathrm{m}$ where the commercial single day trawlers operate regularly (Fig.1). The area also comes under the region where upwelling occurs along the coast. Cruises were conducted at an interval of three months, except during monsoon (June-August). A total of 10 cruises with 30 hauls ( 3 hauls per trip) were performed with each haul lasting for one hour at a speed of 2 nautical miles. The total area covered was about $67 \mathrm{~km}^{2}$ which lies between the geographic coordinates of $74^{\circ} 41.958^{\prime} \mathrm{E}$; $12^{\circ} 53.732^{\prime} \mathrm{N}$ and $74^{\circ} 47.341^{\prime} \mathrm{E}$; $12^{\circ} 53.732^{\prime} \mathrm{N}$. Samples were collected from four stations in the study area.

\section{Sample collection and analysis}

Trawl net with a cod-end mesh of $30 \mathrm{~mm}$ with head rope length of $28.8 \mathrm{~m}$ was used for sampling, covering an area of $3.7 \mathrm{~km} \mathrm{~h}^{-1}$. At the end of each haul, the catch was

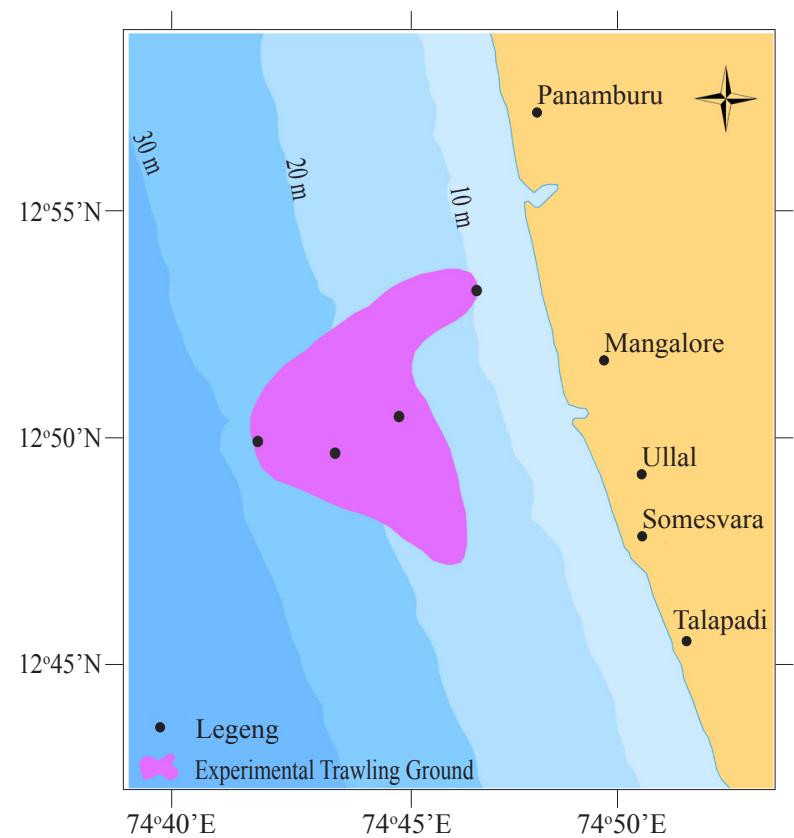

Fig.1. Map showing the experimental trawling ground off Karnataka, south-eastern Arabian Sea brought onboard and the finfishes and shellfishes collected were sorted, counted and weighed. All fishes and shell fishes were identified up to species level (Nelson, 1976; Fischer and Bianchi, 1984; Smith and Heemstra, 1986; Froese and Pauly, 2011). Zooplankton were collected during trawling using a plankton net of mesh size $90 \mu \mathrm{m}$, preserved in formalin and analysed by the method described by Varghese Molly and Krishnan (2009). The zooplankton population was expressed as the number of individuals per cubic metre.

The collection, preservation and analyses of water samples was done following standard methods (Strickland and Parsons, 1972; Grassholf et al., 1983; APHA, 1992) Temperature of the seawater was recorded in situ using a standard mercury glass thermometer and $\mathrm{pH}$ was measured using WTW multiparameter water analyser (Multi 350i) (Merck, Germany). Water samples were collected from all stations for estimating dissolved oxygen (DO), salinity, phosphates and silicates following standard methods (APHA, 2005). For chlorophyll a, $500 \mathrm{ml}$ of water was filtered through a $0.45 \mu \mathrm{m}$ filter at reduced pressure (10 psi). Pigments were extracted from the filters using 90\% acetone and were analysed spectrophotometrically (Parsons et al., 1989). The water sample collected for nutrient analysis $\left(\mathrm{PO}_{4}, \mathrm{NO}_{3}, \mathrm{SiO}_{3}\right)$ was frozen immediately and stored at $-20^{\circ} \mathrm{C}$ until analysis by colorimetric method following Parson et al. (1984).

The 12 month period was divided into three pre-determined seasons, pre-monsoon (February-May), monsoon (June-September) and post-monsoon (OctoberJanuary) seasons (Srinath et al., 2003). The data on species and environmental parameters were pooled seasonally for different stations for further analysis. The total biomass in the area was estimated using the swept area method (Klima, 1976).

\section{Data analyses}

Multivariate statistical tests and ordinations were used to determine the patterns of community structures. The statistical package, Primer v6 proposed by Clarke and Warwick (2001) was used for calculating the diversity indices (Shannon Weiner indices), SIMPER, hierarchical cluster analysis and non-metric multidimensional scaling (MDS) analyses. The square roots of the standardised abundances were used to reduce the considerable influence of the highly abundant species in the community analysis. The multivariate non-metric MDS technique was used to identify seasonal variations in zooplankton composition based on Bray-Curtis similarity. MDS is an unconstrained ordination technique used to create graphical summaries of the relationships among samples based on the abundance of various species present and to highlight the spatial and temporal patterns of the community structure (Clarke and Warwick, 2001). The similarity in species between the seasons was analysed employing similarity percentage (SIMPER) 
analysis using species abundance data. The species that contributed significantly was measured and ranked by this method (Clarke, 1993). MDS and SIMPER were carried out in Primer v6 software (Clarke and Warwick, 2001). The data was subjected to Canonical Correspondence Analysis (CCA) to identify the seasonal variations in fish and zooplankton and their relationship with environmental variables. This method selects a linear combination of environmental variables that maximises the dispersion of the species score (Ter Braak, 1986). This procedure was carried out using EXCELSTAT.

\section{Results}

\section{Fish diversity}

During the study period spanning three seasons, 85 finfish/shellfish species were caught in the trawling grounds of which 41 were finfishes, 24 were crustaceans, 18 molluscs and two echinoderms. Among these, squilla Oratosquilla nepa, flatfish Cynoglossus macrostomus, silverbellies Leiognathus spp. and shrimps were observed during all seasons.

Seasonal analysis showed variations in the species composition with high diversity in the pre-monsoon season (Fig. 2). The average Shannon-Wiener diversity index (H') for pre-monsoon and post-monsoon seasons were 1.45 and 1.26 , respectively. The lowest diversity indices were observed for September (0.82). Dominant species during pre-monsoon and monsoon was Oratosquilla nepa, while during post-monsoon period Cynoglossus macrostomus dominated. Other species abundant during pre-monsoon and post-monsoon were Trichiurus lepturus and Epinephelus diacanthus respectively. The seasonal contributions of major groups of fishes are shown in Fig. 3. SIMPER analysis revealed that major genera contributing to the similarity in pre-monsoon and post-monsoon seasons were Johnius

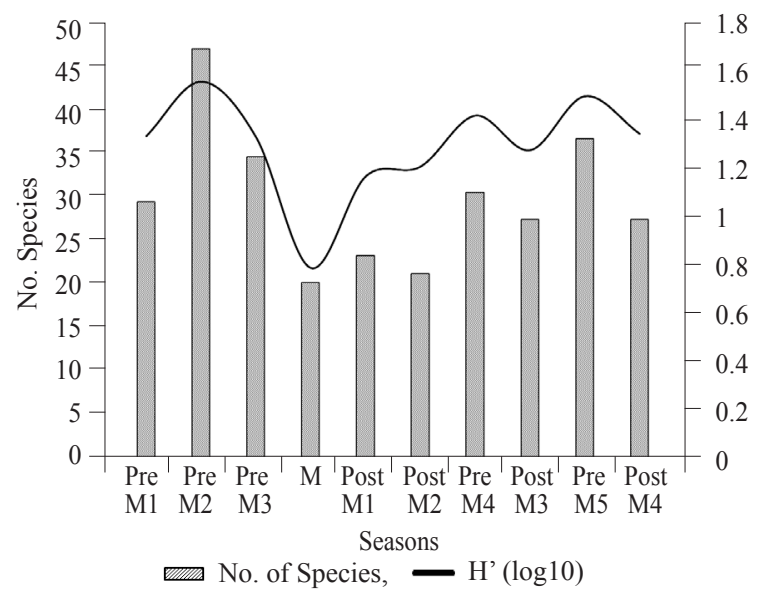

Fig. 2. Seasonal diversity in fishes/shellfishes in the trawling grounds

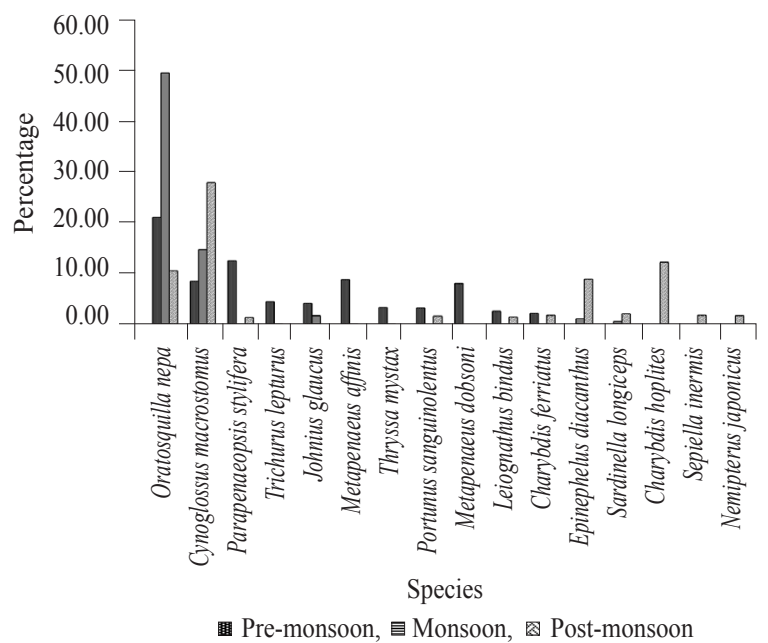

Fig. 3. Seasonal dominant groups in trawling grounds off Mangalore coast

spp. and Cynoglossus spp., respectively. The dissimilarity among these seasons was contributed by Squilla (Table 1). A significant seasonal difference was observed in the trawling grounds for Squilla and Metapenaeus monoceros.

Biomass ranged from 295 to $32397 \mathrm{~kg} \mathrm{~km}^{-2}$ with highest values during post-monsoon season (January) and lowest during September (monsoon) (Fig. 4). During pre-monsoon, the biomass was dominated by Squilla while Cynoglossus spp. dominated during post-monsoon season.

\section{Zooplankton diversity}

Eighteen groups of zooplankton were observed during the study period. The major groups were copepods, chaetognaths, decapod larvae, lucifers, cladocerans, radiolarians, medusae, ctenophores, siphonophores, polychaetes, pteropods, appendicularia, echinoderms, bivalves, gastropod larvae, fish eggs and larvae, amphipods, salps and doliolids. Total zooplankton density (numbers) estimated in the pre-monsoon and post-monsoon seasons were 27437 and $48966 \mathrm{~m}^{-3}$, respectively. Zooplankton showed a significant seasonal $(p<0.01)$ difference between pre-monsoon (Feb-May) and post-monsoon (Oct-Jan) seasons. The diversity was high in the post-monsoon season. Copepods dominated throughout the year, followed by salps and doliolids in the pre-monsoon and cladocerans in the post-monsoon seasons. The SIMPER routine was used to identify the species responsible for the maximum dissimilarity between the seasons. More than $77 \%$ of the seasonal dissimilarity was contributed by 14 species. The dissimilarity between seasons was contributed mainly by cladocerans (Table 2). Results of the analysis showed that major groups contributing to similarity were copepods and decapod larvae in the pre-monsoon and copepods and cladocerans in the post-monsoon seasons. 
Table 1. SIMPER analysis of dissimilarity between seasons - Finfish/Shellfish

Groups: Post-monsoon and Pre-monsoon

Average dissimilarity $=74.49$

\begin{tabular}{|c|c|c|c|c|c|}
\hline \multirow{2}{*}{ Species } & \multirow{2}{*}{$\frac{\text { Post-monsoon }}{\text { Average abundance }}$} & \multirow{2}{*}{$\frac{\text { Pre-monsoon }}{\text { Average abundance }}$} & \multirow{2}{*}{ Average dissimilarity } & \multirow{2}{*}{ Contribution \% } & \multirow{2}{*}{ Cumulative $\%$} \\
\hline & & & & & \\
\hline Squilla & 3.07 & 3.18 & 4.69 & 6.30 & 6.30 \\
\hline Leiognathus spp. & 2.35 & 0.98 & 3.38 & 4.54 & 10.84 \\
\hline Cynoglossus macrostomus & 2.83 & 2.80 & 2.75 & 3.69 & 14.53 \\
\hline Saurida spp. & 1.55 & 0.74 & 2.48 & 3.33 & 17.86 \\
\hline Charybdis cruciata & 0.87 & 1.32 & 2.21 & 2.96 & 20.82 \\
\hline Johnius spp. & 0.66 & 1.96 & 1.81 & 2.43 & 23.25 \\
\hline Parapenaeopsis stylifera & 0.55 & 1.55 & 1.65 & 2.22 & 25.47 \\
\hline Charybdis hoplites & 1.13 & 0.76 & 1.59 & 2.14 & 27.61 \\
\hline Turritella $\mathrm{sp.}$ & 0.60 & 1.30 & 1.54 & 2.07 & 29.68 \\
\hline Panaeus canaliculatus & 0.00 & 1.03 & 1.53 & 2.06 & 31.74 \\
\hline Tibia spp. & 0.92 & 0.61 & 1.52 & 2.05 & 33.78 \\
\hline Thyrssa spp. & 1.03 & 1.47 & 1.52 & 2.03 & 35.82 \\
\hline
\end{tabular}

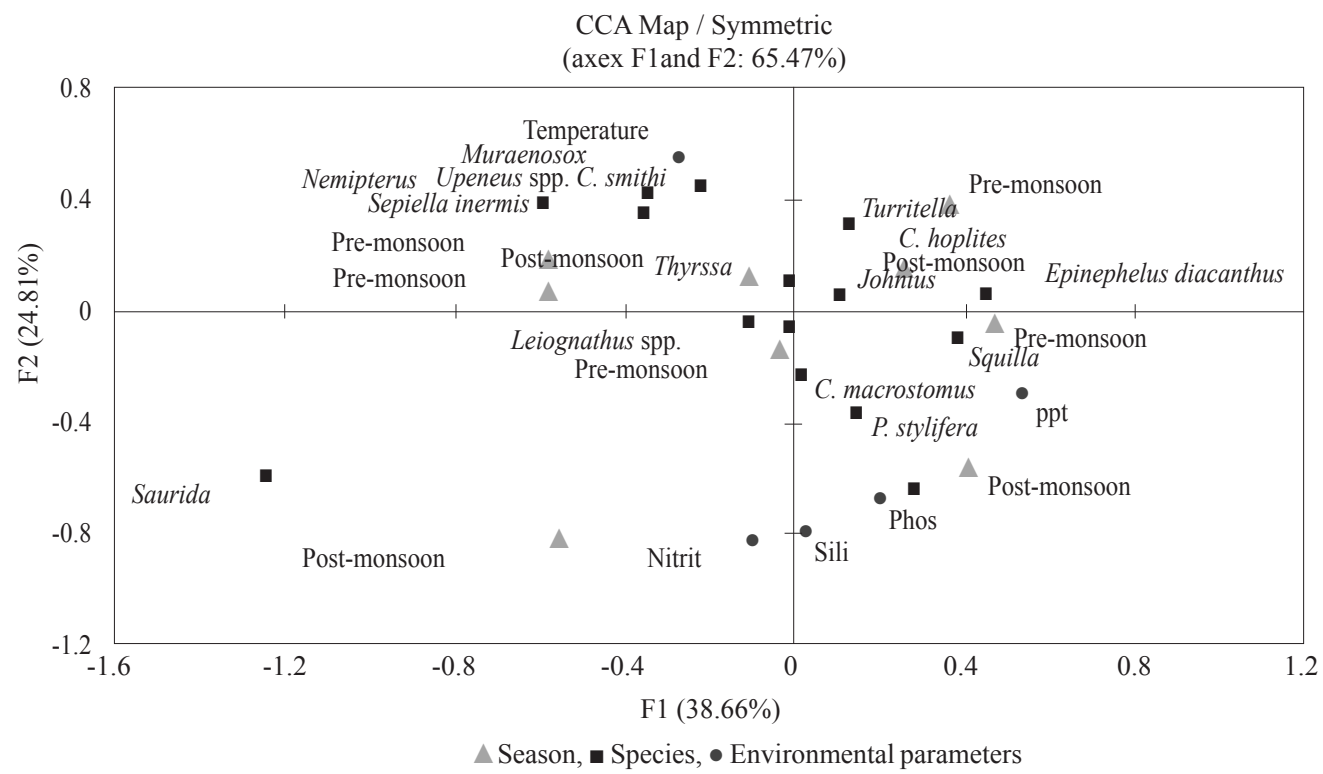

Fig. 4. Canonical correspondence analysis showing the correlation of fish/shellfish with hydrographic parameters

\section{Seasonal hydrography}

The mean values for sea temperature, dissolved oxygen (DO), phosphates, silicates, nitrates and chlorophyll $a$ at surface and bottom waters are given in Table 3. Silicates in surface water correlated negatively with DO $(p<0.01)$, whereas chlorophyll $a$ showed positive correlation with DO $(\mathrm{p}<0.05$; Table 4). A significant positive correlation was also observed between silicates and nitrates $(p<0.01)$. Dissolved oxygen showed variations between seasons with minimum DO recorded in September (monsoon). DO of bottom water $(30 \mathrm{~m})$ showed significant positive correlation with $\mathrm{pH}$. Silicates showed negative correlation with temperature, DO and $\mathrm{pH}$.
CCA was conducted to elucidate the relationships among the assemblages of fishes and shellfishes, zooplankton and the hydrographic variables. Only the major fish and shellfish groups in the trawl catch were considered for CCA analysis. Occurrence of Squilla, C. macrostomus and Parapenaeopsis stylifera were associated with low temperature and showed positive correlations with silicates and phosphates. Squilla also showed a significant negative correlation with temperature and $\mathrm{pH}(\mathrm{p}<0.01)$. Muraenesox, Nemipterus, Sepiella inermis and Charybdis hoplites were associated with high temperatures, whereas Saurida spp. and Leiognathus spp. showed negative correlation with temperature and nitrates (Fig. 5) 
Table 2. SIMPER analysis of dissimilarity between seasons - Zooplankton

Groups: Pre-monsoon and Post-monsoon

Average dissimilarity $=31.02$

\begin{tabular}{|c|c|c|c|c|c|}
\hline \multirow{2}{*}{ Species } & \multirow{2}{*}{$\frac{\text { Pre-monsoon }}{\text { Average abundance }}$} & \multirow{2}{*}{$\begin{array}{c}\text { Post-monsoon } \\
\text { Average abundance }\end{array}$} & \multirow{2}{*}{ Average dissimilarity } & \multirow{2}{*}{ Contribution $\%$} & \multirow{2}{*}{ Cumulative $\%$} \\
\hline & & & & & \\
\hline Cladocera & 14.31 & 83.65 & 8.87 & 28.6 & 28.6 \\
\hline Copepods & 180.04 & 198.09 & 5.71 & 18.42 & 47.02 \\
\hline Fish eggs and larvae & 25.93 & 30.34 & 2.29 & 7.39 & 54.42 \\
\hline Appendicularia & 19.06 & 34.06 & 2.22 & 7.17 & 61.58 \\
\hline Gastropod larvae & 5.24 & 18.43 & 2.17 & 7 & 68.58 \\
\hline Siphonophores & 8.86 & 22.45 & 1.68 & 5.41 & 73.99 \\
\hline Decapod larvae & 20.5 & 18.73 & 1.4 & 4.51 & 78.5 \\
\hline Salps and doliolids & 0 & 10.52 & 1.29 & 4.16 & 82.65 \\
\hline Chaetognaths & 11.77 & 20.12 & 1.21 & 3.91 & 86.56 \\
\hline Pteropods & 9.56 & 12.34 & 1.03 & 3.31 & 89.87 \\
\hline Lucifer & 4.66 & 4.74 & 0.79 & 2.56 & 92.43 \\
\hline
\end{tabular}

Table 3. Hydrographic parameters observed in the trawling grounds

\begin{tabular}{|c|c|c|c|c|}
\hline Hydrographic parameters & & Pre-monsoon & Monsoon & Post-monsoon \\
\hline \multirow[t]{2}{*}{ Sea surface temperature $\left({ }^{\circ} \mathrm{C}\right)$} & $\mathrm{S}$ & $29.6 \pm 0.33$ & $28.6 \pm 0.45$ & $29.1 \pm 0.16$ \\
\hline & $\mathrm{B}$ & $29.9 \pm 0.38$ & $23.5 \pm 0.5$ & $28.59 \pm 0.17$ \\
\hline \multirow[t]{2}{*}{ Dissolved oxygen $\left(\mathrm{ml}^{-1}\right)$} & $\mathrm{S}$ & $4.6 \pm 0.073$ & $5.55 \pm 0.06$ & $5.2 \pm 0.12$ \\
\hline & $\mathrm{B}$ & $4.38 \pm 0.07$ & $2.19 \pm 1.23$ & $4.34 \pm 0.25$ \\
\hline \multirow[t]{2}{*}{ Phosphate ( $\mu$ g-at. $1^{-1}$ ) } & $\mathrm{S}$ & $0.237 \pm 0.044$ & $0.47 \pm 0.23$ & $0.22 \pm 0.04$ \\
\hline & $\mathrm{B}$ & $0.53 \pm 0.1$ & $1.43 \pm 0.69$ & $0.39 \pm 0.085$ \\
\hline \multirow[t]{2}{*}{ Nitrate $\left(\mu \mathrm{g}\right.$-at. $\left.1^{-1}\right)$} & $\mathrm{S}$ & $1.05 \pm 0.26$ & $0.06 \pm 0.033$ & $0.51 \pm 0.16$ \\
\hline & B & $0.56 \pm 0.18$ & $0.37 \pm 0.18$ & $1.84 \pm 0.92$ \\
\hline \multirow[t]{2}{*}{ Silicate ( $\mu \mathrm{g}$-at. $\left.1^{-1}\right)$} & $\mathrm{S}$ & $5.23 \pm 0.73$ & $8.02 \pm 0.54$ & $3.7 \pm 0.53$ \\
\hline & B & $5.13 \pm 0.74$ & $13.67 \pm 1.2$ & $4.62 \pm 1.10$ \\
\hline \multirow[t]{2}{*}{ Chlorophyll a $\left(\mathrm{mg} \mathrm{m}^{-3}\right)$} & $\mathrm{S}$ & $0.38 \pm 0.09$ & $0.07 \pm 0.06$ & $0.32 \pm 0.09$ \\
\hline & B & $0.23 \pm 0.07$ & $0.05 \pm 0.008$ & $0.67 \pm 0.26$ \\
\hline
\end{tabular}

S - Surface, B - Bottom

Table 4. Correlation coefficient (Pearson) between different environmental parameters (surface and bottom) from trawling grounds off Mangalore coast, Eastern Arabian Sea $\left({ }^{*} \mathrm{p}<0.05 ;{ }^{* *} \mathrm{p}<0.001\right)$

\begin{tabular}{|c|c|c|c|c|c|c|c|c|c|}
\hline \multicolumn{10}{|l|}{ Parameters } \\
\hline Surface & Season & SST & $\mathrm{DO}$ & Phosphate & & Nitrate & Nitrite & Silicate & Chlorophyll a \\
\hline Season & & 1 & -0.259 & $0.576^{* * *}$ & -0.043 & -0.372 & 0.135 & -0.343 & -0.078 \\
\hline SST & & & 1 & -0.353 & -0.1869 & 0.112 & 0.089 & 0.108 & -0.112 \\
\hline DO & & & & 1 & -0.0378 & -0.202 & 0.198 & $-0.516^{* *}$ & $0.501^{*}$ \\
\hline Phosphate & & & & & 1 & 0.129 & -0.098 & 0.121 & -0.055 \\
\hline Nitrate & & & & & & 1 & 0.053 & $0.444^{*}$ & -0.047 \\
\hline Nitrite & & & & & & & 1 & -0.185 & -0.024 \\
\hline Silicate & & & & & & & & 1 & -0.323 \\
\hline Chlorophyll a & & & & & & & & & 1 \\
\hline \multicolumn{10}{|l|}{ Bottom } \\
\hline Season & Season & SST & $\mathrm{pH}$ & $\mathrm{DO}$ & Phosphate & Nitrate & Silicate & Chlorophyll a & Squilla \\
\hline Temperature & 1 & -.303 & -.256 & -.005 & -.129 & .236 & -.057 & .272 & $-.354^{*}$ \\
\hline $\mathrm{pH}$ & & 1 & $.761^{* *}$ & $.527^{* *}$ & $-.421^{*}$ & .036 & $-.460^{* *}$ & -.119 & $-.459^{* *}$ \\
\hline DO & & & 1 & $.699^{* *}$ & $-.515^{* *}$ & -.163 & $-.612^{* *}$ & -.032 & $-.458^{* *}$ \\
\hline Phosphate & & & & 1 & $-.515^{* * *}$ & $-.543^{* *}$ & $-.925^{* *}$ & .130 & -.281 \\
\hline Nitrate & & & & & 1 & .179 & $.443^{* *}$ & -.050 & $.370^{*}$ \\
\hline Silicate & & & & & & 1 & $.474^{* *}$ & -.205 & -.232 \\
\hline Chlorophyll a & & & & & & & 1 & -.236 & $.367^{*}$ \\
\hline Squilla & & & & & & & & 1 & -.190 \\
\hline M. monoceros & & & & & & & & & 1 \\
\hline
\end{tabular}




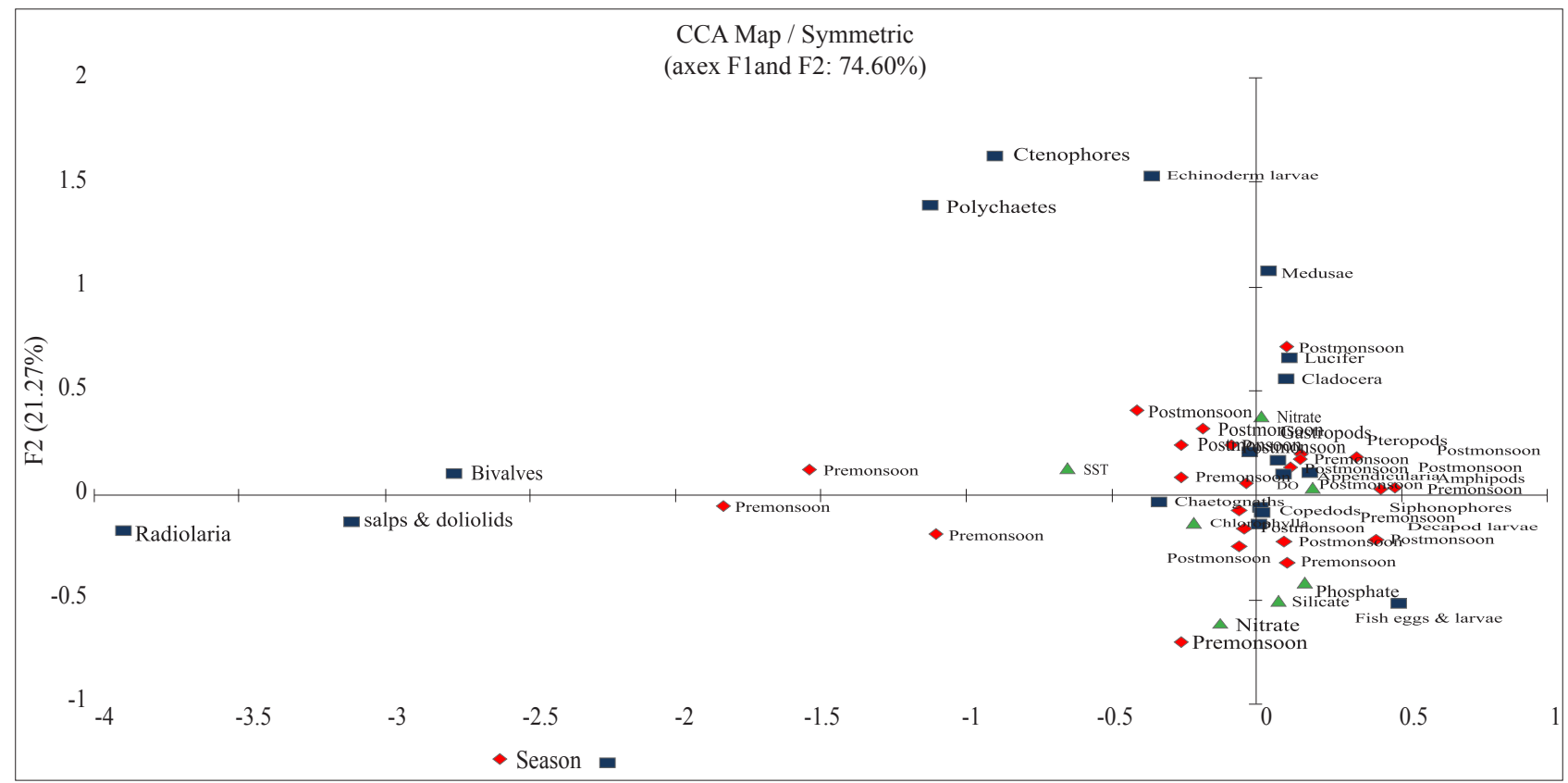

Fig. 5. Canonical correspondence analysis showing the correlation of zooplankton with hydrographic parameters

Abundance of cladocerans and lucifers were high in the post-monsoon season and was associated with high DO and nitrites in the environment. Similarly, copepods were abundant in the post-monsoon season and were associated with high DO, phosphates and chlorophyll $a$ and low SST. Fish eggs and larvae were associated with phosphate, silicate and nitrate levels. Appendicularia and siphonophores preferred high DO and low temperatures during the post-monsoon seasons. Abundance of radiolarians, salps and bivalves were observed in the pre-monsoon season in the environment with high SST and low DO, phosphates and silicates. In addition, the abundance of chaetognaths, decapod larvae, siphonophores and appendicularia was related to high chlorophyll $a$ content. Polychaetes did not show considerable variation with any environmental parameter in a specific season (Fig. 6).

\section{Discussion}

The abundance data of fishes and zooplankton showed seasonal variations thus indicating that biotic communities respond to seasonal environmental variability. The multivariate ordination placed similar fish and zooplankton communities in arrangements which corresponded to seasonal variations. The difference in the community structure was primarily due to differences in relative occurrence and abundance of 3 to 5 species, which were caught regularly from coastal waters during both seasons. Since a seasonal resemblance was observed in fish abundance and environmental parameters (CCA), one or more oceanographic variables were assumed to potentially affect the biotic community structure in the region. Most of the species showed high affinity to temperature and nutrients in the system. The fish biomass in the post-monsoon season was high. The upwelling in the eastern Arabian Sea after the south-west monsoon brings nutrient-rich water to the surface resulting in an increase in the productivity, which is conducive for biomass increase (Panikkar and Jayaraman, 1966; Shankar et al., 2002). The differences in the community structure were mainly due to the differences in relative occurrence and abundance of 4 to 6 species. Thus, the changes in the species composition were not because of abrupt changes in dominant taxa seasonally, but because of a gradient in relative abundance. Similar findings have been reported by Harding et al. (2011) when studying the regional and seasonal patterns of epipelagic fish assemblages.

The major environmental parameters that were found to influence the fish biota during the present study were temperature and nutrients, as the species showed positive or negative affinity towards these variables. CCA of the fish and zooplankton biomass studied in relation to environmental variables facilitated in selecting the two major variables viz. temperature and nutrients, that cause changes seasonally. Thus temperature and nutrients could be considered as key indicators of seasonal differences in the biotic communities studied.

Many studies have investigated the interrelationship between fishes and zooplankton (Chidambaram and Menon, 1945; Subrahmanyan, 1959; Ogawa and Nakahara, 1979; Harding et al., 2011). The pelagic fishes showed a direct 
relationship with zooplankton, whereas the mid pelagic and demersal fishes showed a prey-predator relationship in the marine food web. Among the zooplankton, copepods are dominant in the Arabian Sea (Madhupratap, 1999) and they form a significant part of the diet of many fishes. In this study, copepods were the dominant group of zooplankton and the major group that contributed to seasonal similarity. Copepod is a prey that highly influences its predators in the coastal waters of the south-eastern Arabian Sea (Abdurahiman et al., 2010).

Reduced biomass of fish and shellfishes $\left(\mathrm{kg} \mathrm{km}^{-2}\right)$ was observed in September (monsoon) and was associated with low DO in bottom waters. Seasonal anoxia in the eastern Arabian Sea, following the south-west monsoon, was reported by Naqvi et al. (2009) and Damodar et al. (2012). Dineshbabu et al. (2012) conducted GIS-based resource mapping studies of trawl fisheries off the Mangalore coast. In their study, when bottom trawling commenced immediately after the monsoon season, trawling was carried out beyond $50 \mathrm{~m}$ depth, because of the low abundance of finfishes and shellfishes in the coastal waters during this period. The low abundance of demersal fishes and shrimps in the coastal waters may be because of the formation of an anoxic layer in the bottom waters, which was reflected in this study. The high biomass of fishes obtained in the post-monsoon season may be because of the nutrient inputs brought by the upwelling during south-west monsoon. The coastal upwelling of nutrients occurring during south-west monsoon resulted in rich fisheries in the post-monsoon season in the region (Vivekanandan et al., 2003).

Squilla forms a major component of biomass found up to a depth of $30 \mathrm{~m}$. The SST in the post-monsoon season is lower than that in the pre-monsoon season. Low SST favours the reproduction of Squilla, which have a high affinity towards nutrients in the water. Squilla are a major prey in the trophic guild (where fishes are grouped on the basis of feed similarity) of demersal fishes in the south-eastern Arabian Sea (Abdurahiman et al., 2010) and therefore, Squilla forms a major group in the trophic network in the ecosystem. Squilla found in the trawling grounds can be considered as fishery indicator of a region because ecosystem status indicators often consist of species with common properties, such as foraging guild membership and spatial distribution (Fulton et al., 2005).

The present study investigated species diversity, its seasonal variations and the interaction of biotic community with abiotic factors in coastal waters off Mangalore and the results can contribute towards ecosystem based fisheries management in the region. The data generated can also serve as base line information for evaluating the effects of future trepidations, such as oceanographic changes in relation to climate change or fishing pressure, on fish communities. The analytical techniques used in this study could be effectively utilised for revealing the community structure and its relationship with environmental conditions.

\section{Acknowledgements}

The authors are grateful to Dr. A. Gopalakrishnan Director, ICAR-CMFRI for his constant support and encouragement. The authors also express their gratitude to Shri Poojary and his crew of the trawler which was used for the study. The support rendered by the technical staff of Mangalore Research Centre of ICAR-CMFRI are also gratefully acknowledged.

\section{References}

Abdurahiman, K. P., Nayak,T. H., Zacharia, P. U. and Mohamed, K. S. 2010. Trophic organisation and predator-prey interactions among commercially exploited demersal finfishes in the coastal waters of the south-eastern Arabian Sea. Estuar. Coast. Shelf Sci., 87: 601-610.

Alheit, J., Mollmann, C., Dutz, J., Kornilovs, G., Loewe, P., Mohrholz, V. and Wasmund, N. 2005. Synchronous ecological regime shifts in the central Baltic and the North Sea in the late 1980s. ICES J. Mar. Sci., 62: 1205 - 1215.

APHA 1992. Standard methods for the examination of water and wastewater, $18^{\text {th }}$ edn. American Public Health Association, American Water Works Association \& Water Pollution Control Federation, Washington D.C., USA, 522 pp.

APHA 2005. Standard methods for examination of water and waste water, $21^{\text {st }}$ edn. APHA 1992, AWWA, WPCF, Washington DC, USA.

Bianchi, F., Acri, F., Bernardi, A., Berton, A., Boldrin, A., Camatti, E., Cassin, D. and Comaschi, A. 2003. Can plankton communities be considered as bioindicators of water quality in the lagoon of Venice. Mar. Poll. Bull., 46: 964-971.

Chidambaram, K. and Menon, M. D. 1945. The co-relation of the west coast (Malabar and South Kanara) fisheries with plankton and certain oceanographical factors. Proc. Indian Acad. Sci., 31: $252-286$

Clarke, K. R. 1993. Non-parametric multivariate analyses of changes in community structure. Aust. J. Ecol. 18: 117-143.

Clarke, K. R. and Warwick, R. M. 2001. Change in marine communities: an approach to statistical analyses and interpretation, $2^{\text {nd }}$ edn. PRIMER-E, Plymouth.

CMFRI 2013. Annual report 2012-13. Central Marine Fisheries Research Institute, Kochi, 200 pp.

CMFRI 2014. Annual report 2013-14. Central Marine Fisheries Research Institute, Kochi, 272 pp.

Damodar, M. Shenoy, Sujith, K. B., Mangesh, U., Gauns, Shrikant Patil, Amit Sarkar, Hema Naik, Narvekar, P. V. and Naqvi, S. W. A. 2012. Production of dimethylsulphide during the seasonal anoxia off Goa. Biogeochemistry, 110: 47-55. 
Dineshbabu, A. P. and Radhakrishnan, E. V. 2009. Trawl fishery of juvenile fishes along Mangalore-Malpe Coast of Karnataka and its impact on fish stock. Asian Fish. Sci., 22(2): 491-500.

Dineshbabu, A. P., Thomas Sujitha and Radhakrishnan, E. V. 2012. Spatio-temporal analysis and impact assessment of trawl bycatch of Karnataka to suggest operation based fishery management options. Indian J. Fish., 59 (2): 27-38

Dineshbabu, A. P., Radhakrishnan, E. V., Thomas Sujitha, Maheswarudu, G., Manojkumar, P. P., Kizhakudan Shoba Joe, Pillai, S. Lakshmi, Chakraborty Rekha, D., Josileen Jose, Sarada, P. T., Sawant Paramita Banerjee, Philipose, K. K., Deshmukh, V. D., Jayasankar, J., Ghosh Shubhadeep, Koya Mohammed, Purushottama, G. B. and Dash Gyanaranjan 2013. Appraisal of trawl fisheries of India with special reference on the changing trends in bycatch utilisation. J. Mar. Biol. Ass. India, 55(2): 69-78.

Edwards, M., Philip Reid and Benjamin Planque 2001. Long-term and regional variability of phytoplankton biomass in the North-east Atlantic (1960-1995). ICES J. Mar. Sci., 58: 39-49.

Fischer, W. and Bianchi, G. 1984. FAO Species identification sheets for fishery purpose, Western Indian Ocean (Fishing Area 51). FAO, Rome, Italy.

Froese, R. and Pauly, D. 2011. Fish base, World Wide Web electronic publication. www.fishbase.org. (Accessed 28 December 2015).

Fulton, E. A., Smith, A. D. M. and Punt, A. E. 2005. Which ecological indicators can robustly detect effects of fishing? ICES J. Mar. Sci., 62: 540-551.

Grasshoff, K., Ehrhardt, M. and Lremling, K. 1983. Methods of seawater analysis, $2^{\text {nd }}$ edn. Verlag Chemie, Weinheim, $600 \mathrm{pp}$.

Harding, J. A. Arnold, J. Ammann and Bruce MacFarlane, R. 2011. Regional and seasonal patterns of epipelagic fish assemblages from the central California Current. Fish. Bull., 109: 261-281.

Klima, E.F. 1976. A review of the fishery resources in the Western Central Atlantic, WECAF Stud., 3: 1-77

Kurup, K. N., Nair, G. K. K, Annam, V. P., Kant, A., Beena, M. R. and Kambadkar, L. 1987. An appraisal of the marine fisheries of Karnataka and Goa. Special Publication no..36, Central Marine Fisheries Research Institute, Kochi, 104 pp.

Madhupratap, M. 1999. Some special features of the trophic relationship in the Arabian Sea. In: Qasim, S. Z. (Ed.), India's EEZ, Omega Scientific Publishers, New Delhi, 87 pp.

Mohamed, K. S., Muthiah, C., Zacharia, P. U., Sukumaran, K.K., Rohit, Prathibha and Krishnakumar, P. K. 1998. Marine fisheries of Karnataka State, India. NAGA, The ICLARM Quarterly, 21(2): 10-15.

Naqvi, S. W. A., Hema Naik, Amal Jayakumar, Anil K. Pratihary, Gayatri Narvenkar, Siby Kurian, Rajesh Agnihotri, M. S., Shailaja and Pradip V. Narvekar 2009. Seasonal anoxia over the western Indian continental shelf. Indian Ocean
Biogeochemical Processes and Ecological Variability. Geoph Monog. Series, 185: 333-345.

Nelson, J. S. 1976. Fishes of the world. Wiley-Interscience, New York, $416 \mathrm{pp}$.

Ogawa, Y. and Nakahara, T. 1979. Interrelationships between pelagic fishes and plankton in coastal fishing ground of the south-western Japan Sea. Mar. Ecol. Prog. Ser., 1: 115-122.

Panikkar, N. K. and Jayaraman, R. 1966. Biological and oceanographic differences between the Arabian Sea and the Bay of Bengal as observed from the Indian region. Proc. Indian Acad. Sci., B, 64(5): 231-240.

Parson, T. R., Maita, Y. and Lalli, C. M. 1984. A manual of chemical and biological methods of seawater analysis. Pergamon Press, New York, 173 pp.

Parsons, T. R., Matta, Y. and Lalli,C. M.1989. A manual of chemical and biological methods of seawater analysis. Pergamon Press, New York, 173 pp.

Roy, U., Biplab Kumar Shaha, Mazhabuddin, K. H., Fazlul Haque M. D. and Golam Sarower, M. D. 2010. Study on the diversity and seasonal variation of zooplankton in a brood pond Bangladesh. Mar. Res. Aqua., 1: 30-37.

Shankar, D., Vinayachandran, P. N. and Unnikrishnan, A. S. 2002 The monsoon currents in the north Indian Ocean. Prog. Oceanogr., 52: 63-120.

Smith, M. M. and Heemstra,P. C. 1986. Smith's sea fishes. Springer Verlag, New York, 1047 pp.

Srinath, M., Pillai, V. N., Vivekanandan, E and Kurup, K. N. 2003. Demersal fish assemblages of the south-west coast of India. In: Silvestre, G., Garces, L., StobutzkiI, Ahmed, M., Valmonte-Sanos, R. A., Luna, C., Lachica-Alino, L., Munro, P., Christensen, V. and Pauly, D. (Eds.), Assessment, management and future directions for coastal fisheries in Asian countries, World Center Conference Proceedings, 67: 63-186.

Strickland, J. D. H and Parsons, T. R. 1972. A practical handbook of seawater analysis, $2^{\text {nd }}$ edn. Fisheris Research Board of Canada, Bulletin 167, Ottawa, 310 pp.

Subrahmanyan, R. 1959. Studies on the phytoplankton of the west coast of India. Proc. Indian Acad. Sci., 50: 115-252.

Subrahmanyan, R. 1973. Hydrography and plankton as indicators of marine resources. In: Proceedings of the symposium on living resources of the seas around India 1968. Mandapam Camp, Tamil Nadu, India, p. 199-228.

Ter Braak, C. J. F. 1986. Canonical correspondence analysis: a new eigenvector technique for multivariate direct gradient analysis. Ecology, 67: 1167-1179.

Varghese Molly and Krishnan, L. 2009. Distribution of zooplankton in selected centres of Cochin backwaters Kerala. J. Mar. Biol. Ass. India, 51(2): 194-198. 
Vivekanandan, E., Srinath, M., Pillai, V. N., Immanuel, S. and Kurup, K. N. 2003. Marine fisheries along the south-west coast of India. In: Silvestre, G., Garces, L., Stobutzki, I., Ahmed, M., Valmonte-Sanos, R. A., Luna, C., Lachica-Alino, L.,
Munro, P., Christensen,V. and Pauly, D. (Eds.), .Assessment, management and future directions for coastal fisheries in Asian countries, World Center Conference Proceedings, p. 757-792.

Date of receipt $\quad: 27.10 .2015$

Date of acceptance : 15.09 .2016 